\title{
MUTAGENESIS IN Tradescantia pallida AS A BIOMARKER OF THE EFFECTS OF WATER POLLUTED WITH URBAN EFFLUENT
}

\author{
MUTAGÊNESE EM Tradescantia pallida COMO \\ BIOMARCADOR DE EFEITOS DE EFLUENTES \\ URBANOS POLUÍDOS
}

\section{Ana Lúzia de Souza Araújoㅜㅜ ; Eliane Tigre Guimarães² Robson Seriani $^{3}$}

${ }^{1}$ Pós-graduada em Gestão Ambiental - Ecogestão - Universidade Paulista. UNIP. São Paulo - SP, Brasil.

${ }^{2}$ Laboratório de Poluição Atmosférica Experimental da Faculdade de Medicina da USP. LIM-HC-FMUSP. São Paulo - SP, Brasil.

${ }^{3}$ Professor convidado da Pós-graduação em Gestão Ambiental - Ecogestão da Universidade Paulista - UNIP

\begin{abstract}
The present paper evaluated the toxicity of effluent released into the Tiete River, in Barra Bonita City, São Paulo State, using the test micronucleus with Tradescantia pallida. Young inflorescences of $T$. pallida $(\mathrm{n}=20)$ were partially immersed in one of three treatments: water containing effluent, a positive control $(0.1 \%$ formaldehyde), and a negative control (distilled water). The results showed a statistically significant difference $(p<0.05)$ between groups, indicating the genotoxicity of the effluent.
\end{abstract}

Keywords: Tradescantia. Micronuclei. Bioassay. Genotoxicity.

\section{RESUMO}

O presente estudo avaliou a toxicidade de efluentes lançados no Rio Tietê, na cidade de Barra Bonita/SP, utilizando o teste do micronúcleo em Tradescantia pallida. Inflorescências jovens $(\mathrm{n}=20)$ de $T$. pallida foram parcialmente imersas em água do efluente e os outros dois grupos: controle positivo ( $0,1 \%$ de formaldeído) e controle negativo (água destilada). Os resultados mostraram uma diferença estatisticamente significativa $(\mathrm{p}<0,05)$ entre os grupos, indicando genotoxicidade do efluente.

Palavras-chave: Tradescantia. Micronúcleos. Bioensaio. Genotoxicidade.

Toxicity tests using plants are an efficient tool for biomonitoring and evaluation of the genotoxicity of environmental contaminants (UMBUZEIRO et al., 2007; GUIMARÃES and PEDROSO, 2012). Clones of the genus Tradescantia have been used in genotoxicity tests and 
biomonitoring (MISÍK et al., 2011) of pollutants, pesticides, and herbicides (RODRIGUES et al., 1996; RODRIGUES et al., 1997).

The Tradescantia micronucleus bioassay (Trad-MCN) is a cytogenetic test that can easily be counted. The Trad-MCN consists of a set of procedures for exposure of young inflorescences of Tradescantia to contaminants and quantification of micronuclei formed in pollen mother-cells, visible at the young tetrad stage (MA, 1981). Trad-MCN has been used to evaluate the genotoxicity of water, air, and soil and of potential mutagens (RODRIGUES, 1999; PRAJAPATI and TRIPATHI, 2008; SAVÓIA et al., 2008; MISÍK et al., 2011).

Clones are used for their genetic uniformity, reducing variability in response and allowing improved interpretation of results. However, difficulties in obtaining and maintaining the plant, particularly in tropical regions, limit its use.

T. pallida has been reported to be an effective tropical substitute for Tradescantia clones in the micronucleus test (SUYAMA et al., 2002; MIELLI et al., 2009), and it employed in the present study.

In urban areas where industrial effluents are discharged, the increased of the micronuclei have been observed in tetrads of T. pallida (UMBUZEIRO et al., 2007), and genotoxicity has been reported in Allium cepa exposed to samples from the Paraiba do Sul River (OLIVEIRA et al., 2011). According to Von Sperling (1996) and Abessa (2003) wastewater's toxicity to aquatic organisms is due to the presence of numerous organic and inorganic compounds.

The present study evaluated the genotoxicity of water near an area where urban effluent is released into the Tiete River in Barra Bonita city, São Paulo State by measuring the frequency of micronuclei T. pallida (Trad-MCN).

The urban effluent, obtained near the city center, is a mixture of urban runoff and treated sewage, which are both released into the Tiete River $\left(22^{\circ} 29^{\prime} 59.39^{\prime \prime}-48^{\circ} 33^{\prime} 52.30^{\prime \prime} \mathrm{W}\right)$. Water quality was determined by measuring $\mathrm{pH}$, conductivity $(\mu \mathrm{S})$, dissolved oxygen $(\mathrm{mg} / \mathrm{L})$, temperature $\left({ }^{\circ} \mathrm{C}\right)$, and dissolved solids (mg/L) (APHA, 2005). Following these analyses, the samples were refrigerated $\left(4^{\circ} \mathrm{C}\right)$ and forwarded to the laboratory for tests of mutagenicity using T. pallida.

\section{METODOLOGIAS}

The inflorescences of $T$. pallida used in the bioassay were obtained from a wooded field considered to be a reference area (MIELLI et al., 2009). Only turgid inflorescences were used for the experiment.

Sixty cuttings with young inflorescences (approximately $15 \mathrm{~cm}$ ) were divided equally into three groups and maintained for $24 \mathrm{~h}$ partially immersed in $400 \mathrm{~mL}$ of potable water, with constant aeration. Next, the potable water was replaced with the test solutions: negative control (distilled water), positive control ( $0.1 \%$ formaldehyde in distilled water), and effluent. The cuttings were partially immersed for $8 \mathrm{~h}$ in the test solutions (exposure period). After exposure, the cuttings were returned to potable water for $24 \mathrm{~h}$ (recovery time) as required for the progress of meiosis and for the stem cells of pollen grains to reach the stage of early tetrads (MA, 1983).

Following the exposure and recovery time, the inflorescences were fixed in solution of acetic acid and ethanol (1:3), as previously reported (MA, 1981). To prepare slides for viewing, samples were dissected with needles; the glumes were removed to expose the buds, which were placed on glass slides, and acetocarmine was added. Ten slides were prepared for each group, and a randomly chosen group of 300 tetrads was counted on each slide at a magnification $400 \mathrm{X}$ using a light microscope (ZEISS, GERMANY). The frequency of micronuclei was expressed as a percentage (total number of micronuclei per 100 tetrads). The Shapiro-Wilks test was used to test for normality and ANOVAs were performed to compare groups $(p<0.05)$. 


\section{RESULTS AND DISCUSSION}

The physical and chemical parameters of the effluent are shown in Table 1.

Table 1 - Physico-chemical parameters of the effluent and Brazilian Legislation (Conselho Nacional do Meio Ambiente) CONAMA 357/05 (BRASIL, 2005).

\begin{tabular}{l|c|c}
\hline Parameter & Urban Effluent & CONAMA 357/05 (Class II) \\
\hline $\mathrm{pH}$ & 8.05 & $6-9$ \\
Conductivity ( S) & 127 & 100 \\
Dissolved Oxygen (mg/L) & 1.03 & $\geq 6$ \\
Temperature $\left({ }^{\circ} \mathrm{C}\right)$ & 21.11 & - \\
Dissolved solids $(\mathrm{mg} / \mathrm{L})$ & 0.083 & 500 \\
\hline
\end{tabular}

The frequency of micronuclei in T. pallida in each of the three groups is shown in Figure 1. Urban effluent caused an increase in the frequency of micronuclei in $T$. pallida compared to the control group $(p<0.05)$. The frequency of micronuclei in $T$. pallida exposed to effluent did not differ significantly from the positive control $(p>0.05)$. The micronuclei frequency observed in the positive control group differed significantly $(p<0.01)$ from the negative control (Figure 1$)$.

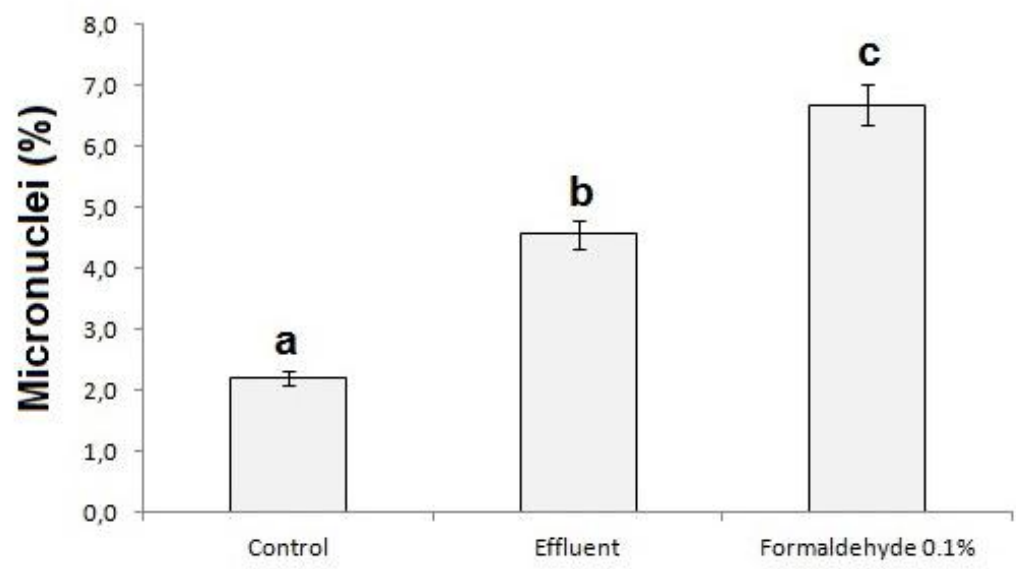

Figure 1. Frequency of micronuclei in T. pallida in the 3 groups: negative control (distilled water), effluent, and positive control ( $0.1 \%$ formaldehyde). The negative control (a) $\neq$ effluent (b) $(p<0.05)$ and effluent (b) $\neq$ formaldehyde $0.1 \%$ (c) $(p<0.01)$. The formaldehyde $0.1 \%$ (c) $\neq$ control (a) $(p<0.001)$.

The percentage of micronuclei observed in T. pallida exposed to effluent differed from the negative control group, indicating genotoxicity. Thus, the effluent collected is considered polluted. The conductivity and dissolved oxygen parameters are nonstandard CONAMA 357/05 (BRASIL, 2005), indicating the presence of pollutants (CETESB, 2009). The conductivity of effluent was high (127 S/cm). According to CONAMA 357/05, the maximum value for unpolluted water is 100 
S/cm. Conductivity provides an indirect measure of the concentration of pollutants. In general, levels above 100 S/cm indicate impacted environments (CETESB, 2009).

The value obtained for dissolved oxygen of the effluent was $1.06 \mathrm{mg} / \mathrm{mL}$ being in disagreement with the standard CONAMA 357/05 (BRASIL, 2005). Conductivity serves as an indicator of substances such as domestic sewage and industrial waste in aquatic ecosystems. Oxygen is also an indicator of contamination by organic effluents (VON SPERLING, 1996).

There is no evidence that nonstandard value for these two parameters cause genotoxicity; however, they are indicators of an environment impacted by domestic and industrial effluents (CETESB, 2009) which also contains genotoxic substances (DUAN et al., 1999; STEINKELLNER et al., 1999; THEWES et al., 2011) regardless of more specific analyses. Urban effluent is one of the main sources of contaminants, which includes a myriad of organic substances as well as residues of medicines, metals, hydrocarbons, pesticides, and other toxic contaminants, whereas detergents are commonly associated with sewage (ABESSA et al. 2005, 2008; AMBROZEVICIUS and ABESSA, 2008; PEREIRA et al., 2012; SERIANI et al., 2013).

\section{CONCLUSIONS}

The genus Tradescantia is sensitive to potentially genotoxic environmental contaminants, as previously described (KLUMPP et al., 2006; MIELLI et al., 2009). In our study, T. pallida was effective in evaluating the toxic effects of genotoxic pollutants presents in urban effluents. Thus, micronuclei represent a simple, efficient, fast, and inexpensive alternative method to evaluate the genotoxic potential of environmental contaminants (BATALHA et al., 1999).

In this study, it detected the presence of mutagenic agents in urban effluent by measuring increased numbers of micronuclei in tetrads of T. pallida. However, the active elements could not be identified.

\section{REFERENCIAS}

ABESSA, D.M.S. Avaliação ecotoxicológica da água do rio Pirajussara (SP. Brasil). O Mundo da Saúde, Centro Universitário São Camilo, São Paulo, n. 4, p. 543-550, 2003.

ABESSA, D.M.S.; CARR, R.S.; RACHID, B.R.F.; SOUSA, E.C.P.M.; HORTELLANI, M.A.; SARKIS, J.E. Influence of a brazilian sewage outfall on the toxicity and contamination of adjacent sediments. Marine Pollution Bulletin, Elsevier Editorial System, v. 50, p. 875-885, 2005.

ABESSA, D.M.S.; CARR, R.S.; SOUSA, E.C.P.M.; RACHID, B.R.F.; ZARONI, L.P.; PINTO, Y.A.; GASPARRO, M.R.; BÍCEGO, M.C.; HORTELLANI, M.A.; SARKIS, J.E.S.; MUNIZ, P. Integrative Ecotoxicological Assessment of a Complex Tropical Estuarine System. Chapter 4, p.136. In: Hoffer, T.N. (ed) Marine Pollution: New Research. Nova Science Publishers Inc., New York. 2008

AMBROZEVICIUS, A.P.; ABESSA, D.M.S. Acute toxicity of waters from the urban drainage channels of Santos (São Paulo, Brazil). Pan-American Journal of Aquatic Sciences. Panamjas, Brazil, v. 3, n. 2, p. 108-115, 2008.

APHA - American Public Health Association. Standard Methods for the examination of water and Wastewater, $21^{\mathrm{a}}$ Ed., Wa American Public Health Association, AWWA - American Water Works Association and WPCF - Federation, 2005. 
BRASIL. Resolução CONAMA n ${ }^{\circ}$ 357, de 17 de março de 2005. Classificação de águas, doces, salobras e salinas do Território Nacional. Publicado no D.O.U.

CETESB - Companhia de Tecnologia de Saneamento Ambiental. Relatório da qualidade das águas superficiais no Estado de São Paulo, 2010. 310 p.

CETESB. Companhia Ambiental Do Estado De São Paulo. Qualidade das águas interiores no Estado De São Paulo. Significado ambiental e sanitário das variáveis de qualidade das águas e dos sedimentos e metodologias analíticas e de amostragem. Série Relatórios Apêndice A, 2009.

DUAN, C.Q.; HU, B.; WANG, Z.H.; WEN, C.H.; YAN, S.Q.; JIANG, X.H.; WANG, D.K.; LI, Q.; LIANG, X.F. Tradescantia bioassays for the determination of genotoxicity of water in the Panlong River, Kunming, People's Republic of China. Mutatation Research. Elsevier, v. 19, n. 426(2), p. 127-31, 1999.

GUIMARÃES, E.T.; PEDROSO, A.N.V. Genotoxicity and Air Pollution. Encyclopedia of Environmental Management. $1^{\circ}$ ed. Copenhague: Taylor and Fancis, 2012, v. 3, p. 2102-2110.

KLUMPP, A.; ANSEL, W.; KLUMPP, G.; CALATAYUD, V.; GARREC, J.P.; HE, S.; PENUELAS, J.; RIBAS, A.; RO-POULSEN, H.; RASMUSSEN, S.; SANZ, M.J.; VERGNE, P. Tradescantia micronucleus test indicates genotoxic potential of traffic emissions in European cities. Environmental Pollution, Elsevier, v. 139, p. 515 -522, 2006.

MA, T.S. Tradescantia micronucleus bioassay and pólen tube chomatid aberration test for in situ monitoring and mutagen Screening. Environmental Health Perspectives, National Institute of Environmental Health Sciences, National Institutes of Health, U.S. Department of Health and Human Services, v. 37, p. 85-90, 1981.

MA, T.H. Tradescantia Micronuclei (Trad-Mcn) Test For Environmental Clastogens. In: Kolber, A.R.; Wong, T.K.; Grant, L.D.; Dewoskin, R.S.; Hughes, T.J., (Ed). In: Vitro Toxicity Testing of Environmental Agents. Current and Future Possibilities. Part A: Survey Of Test Systems. New York: Plenum Press, p.191-214, 1979.

MIELLI, A.C. Avaliação da atividade genotóxica de lodo de esgoto tratado do Estado de São Paulo com teste de micronúcleo em células germinativas de Tradescantia (Trad-MCN). 2008, 107f. Tese (Doutorado na Faculdade de Medicina de São Paulo), Universidade de São Paulo, 2008.

MIELLI, A.C.; SALDIVA, P.H.N.; UMBUZEIRO, G.A. Comparação entre as respostas do Clone 4430 e Tradescantia pallida no teste de micronúcleo (Trad-MCN), Journal of Brazilian Society of Ecotoxicology, Brasil, v. 4, n. 1-3, p. 49 - 54, 2009.

MISÍK, M.; MA, T.H.; NERSESYAN, A.; MONRCA, S.; KIM, J.K.; KNASMUELLER, S. Micronucleus assays with Tradescantia pollen tetrads: an update. Mutagenesis, Oxford, v. 26, p. 215-221, 2011.

OLIVEIRA, L.M; VOLTOLINI, L.C; BARBÉRIO, A. Potencial mutagênico dos poluentes na água do rio Paraíba do Sul em Tremembé, SP, Brasil, utilizando o teste Allium cepa. Revista Ambiente \& Água - An Interdisciplinary Journal of Applied Science Taubaté, SP., v. 6, n. 1, 2011. , p. 90103,2011 
PEREIRA, C.D.; MARTÍN-DÍAZ, M.L.; CATHARINO, M.G.; CESAR, A.; CHOUERI, R.B.; TANIGUCHI, S.; ABESSA, D.M. BÍCEGO, M.C.; VASCONCELLOS, M.B. BAINY, A.C.; SOUSA, E.C.; DELVALLS, T.A. Chronic contamination assessment integrating biomarkers' responses in transplanted mussels-a seasonal monitoring. Environmental Toxicology. Springer, São Paulo, v. 27, n. 5, 257-67, 2012.

PRAJAPATI, S.K.; TRIPATHI, B.D. Assessing the genotoxicity of urban air pollutants in Varanasi City using Tradescantia micronucleus (Trad-MCN) bioassay. Environment International, Elsevier, v. 34, p. 1092-1096, 2008.

RODRIGUES G.S. Bioensaio de Toxicidade Genética com Tradescantia. - EMBRAPA, Jaguariúna, São Paulo, 1999, 56p.

SAVÓIA, E.J.L.; DOMINGOS, M.; GUIMARÃES, E.T.; BRUMATI, F.; SALDIVA, P.H.N. Biomonitoring genotoxic risks under the urban weather conditions and polluted atmosphere in Santo André, SP, Brazil, through Trad-MCN bioassay. Ecotoxicology and Environmental Safety. Elsevier, v. 72, n. 1, p. 255-260, 2008.

SERIANI, R, ABESSA, D. M. S, PEREIRA, C. D. S., KIRSCHBAUM, A. A., ASSUNÇÃO, A; RANZANI-PAIVA, M. J. T. Influence of seasonality and pollution on the hematological parameters of the estuarine fish Centropomus parallelus. Brazilian Journal of Oceanography, Instituto Oceanográfico, USP., v.61, n.2, p. 105-111, 2013.

STEINKELLNER, H.; KASSIE, F.; KNASMÜLLER, S. Tradescantia-Micronucleus assay for the assessment of the clastogenicity of Austrian water. Mutation Research, Elsevier B.V., v. 19, n. 426 (2), p. 113-116, 1999.

SUYAMA, F.; GUIMARÃES, E.T.; LOBO, D.J.A.; RODRIGUES, G.S.; DOMINGOS, M.; ALVES, E.S.; CARVALHO, H.A.; SALDIVA, P.H.N. Pollen mother cells of Tradescantia clone 4430 and Tradescantia pallida var. Purpurea are equally sensitive to the clastogenic effects of Xrays. Brazilian Journal of Medical and Biological Research, Associação Brasileira de Divulgação Científica (ABDC), v. 35, p. 127-129, 2002.

THEWES, M.R.; JUNIOR, D.E.; DROSTE, A. Genotoxicity biomonitoring of sewage in two municipal wastewater treatment plants using the Tradescantia pallida var. Purpurea bioassay. Genetic Molecular Biology, Sociedade Brasileira de Genética, v. 34, n.4, 689-693, 2011.

UMBUZEIRO, G.A.; COIMBRÃO, C.A.; KUMMROW, F.; LOBO, D.J.A.; SALDIVA, P.H.N. Mutagenic Activity Assessment of Cristais River, São Paulo, Brazil, Using the Blue Rayon/Salmonella Microsome and the Tradescantia pallida Micronuclei Assays. Journal of the Brazilian Society of Ecotoxicology, Universidade do Vale do Itajaí, Itajaí, SC., v. 2, n. 2, 163-171, 2007.

VON SPERLING, M. Introdução à qualidade das águas e o tratamento de esgotos. $2^{\mathrm{a}}$ ed. Belo Horizonte. Departamento de Engenharia Sanitária e Ambiental, Universidade Federal de Minas Gerais, 1996. 196 p. 